\title{
ANALISA MASALAH-MASALAH YANG MUNCUL DALAM PEMEKARAN WILAYAH BARU PADA PENYELENGARAAN OTONOMI DAERAH
}

\author{
SURYA AKBAR \\ Program Studi Ilmu Administrasi Negara STIA Indragiri \\ Jl. Azki Aris, Rengat. Kode Pos 29318. Telp. (0769) 22458
}

\begin{abstract}
Abstrak :
Studi ini bertujuan untuk memahami penyelenggaraan otonomi daerah atau desentralisasi yang bertujuan untuk meningkatkan kualitas pelayanan, daya saing daerah dan kesejahteraan masyarakat, namun dalam penelitian ini selanjutnya akan menguraikan secara jelas otonomi daerah mampu memberikan rangsangan kepada daerah untuk menjadi daerah otonomi baru atau daerah pemekaran baru. Pembentukan daerah otonomi baru merupakan hal yang biasa jika hal itu mampu mewujudkan keinginan masyarakat daerah karena yang jelas dengan munculnya daerah otonomi baru akan memunculkan pula permasalahan baru. Ada dampak positif dan dampak negatif membayangi pelaksanaan otonomi daerah khusunya bagi daerah otonomi baru. Lahirnya daerah otonomi baru diharapkan berdasarkan atas keinginan masyarakat yang mampu meningkatkan partisipasi masyarakat dalam membangun daerah dan bukan atas keinginan elite lokal saja.
\end{abstract}

Kata Kunci : Otonomi daerah, desentralisasi, partisipasi dan elite lokal

\section{Abstract :}

This study aims to understand the implementation of regional autonomy or decentralization which aims to improve service quality, regional competitiveness and community welfare, but in this study it will further explain clearly that regional autonomy is able to provide stimulus to the regions to become new autonomous regions or new areas of expansion. The formation of a new autonomous region is normal if it is able to realize the desires of the local people because what is clear with the emergence of new autonomous regions will also raise new problems. There are positive impacts and negative impacts overshadowing the implementation of regional autonomy especially for the new autonomous region The birth of the new autonomous region is expected to be based on the wishes of the people who are able to increase community participation in building the region and not at the wishes of the local elite.

Keywoord : Regional autonomy, decentralization, participation and local elite

\section{Pendahuluan}

Negara Indonesia merupakan sebuah negara kepulauan yang merdeka dan berdaulat yang terletak wilayah Asia Tengara, secara astronomis Indonesia terletak pada $6^{\circ} \mathrm{LU}-11^{\circ} \mathrm{LS}$ dan $95^{\circ} \mathrm{BT}-$ $141^{\circ} \mathrm{BT}$. Adapun secara geografis, Kepulauan Indonesia terletak di antara Benua Asia dan Benua Australia serta di antara Samudera Hindia dan Samudera 
Pasifik. Batas wilayah Indonesia yaitu (Gayo, 2010: 269).

- Sebelah utara: Laut Cina Selatan dan Samudra Pasifik

- Sebelah timur: Papua Nugini.

- Sebelah selatan: Samudra Hindia.

- Sebelah barat: Samudra Hindia.

Berdasarkan data Bank Dunia (World Bank) hingga tahun 2013 jumlah penduduk indonesia berjumlah 249,9 juta jiwa. Luas wilayah Indonesia mencapai $5.194 .143 \mathrm{~km} 2$ (Penduduk Indonesia Tahun 2013; http://indonesia2050.info/umum/luaswilayah-dan-jumlah-penduduk/; diakses tanggal 06 November 2018). Dua pertiga dari luas wilayah Indonesia berupa lautan. Negara indonesia terdiri atas 7 kepulauan besar diantaranya kepulauan Kalimantan, kepulauan Sumatera, Jawa, Nusa Tenggara, Sulawesi, Maluku dan Papua.

Luasnya wilayahnya Indonesia disertai dengan banyaknya jumlah provinsi yang ada saat ini yakni indonesia terdiri dari 34 Provinsi, berdasarkan sumber data yang dihimpun dari ensiklopedia tahun 2015-2016 jumlah kabupaten yang ada di indonesia adalah sebanyak 416 Kabupaten dan sebanyak 98 Kota yang tersebar diseluruh wilayah indonesia, dengan demikian jumlah seluruh kabupaten dan kota yang ada di indonesia saat ini adalah 514 Kabupaten dan Kota. Selain itu, Badan Pusat Statistik (BPS) hingga tahun 2014 mencatat jumlah desa menurut provinsi dan letak geografis terdiri dari desa di wilayah tepi laut berjumlah 12.827 desa dan desa yang terletak di wilayah bukan tepi laut berjumlah 69.363 desa, jadi jumlah seluruh desa yang ada di Indonesia pata tahun 2014 tercatat sebanyak 82.190 desa yang tersebar diseluruh wilayah kesatuan republik indonesia.

Indonesia memiliki beberapa pulau besar yang telah dihuni dan diberi nama seperti uraian sebelumnya, namun sebenarnya masih banyak lagi pulau yang tersebar diseluruh wilayah kesatuan republik indonesia, baik yang telah dihuni dan diberi nama ataupun tidak berpenghuni dan mungkin belum diberi nama. Hal ini merupakan anugerah yang luar biasa terhadap tanah air yang kita cintai ini. Berdasarkan data ensiklopedia yang juga dimuat dalam terbitan kompas tahun 2016 pulau di indonesia sebenarnya berjumlah 17.504 buah pulau (Kompas, 2016).

Begitu besar potensi yang dimiliki oleh bangsa indonesia, baik itu dilihat dari luas wilayahnya maupun segala sumber daya khususnya sumber daya alam yang terkandung didalamya. Kekayaan sumber daya alam indonesia sebagian telah dimanfaatkan untuk memenuhi kebutuhan bangsa Indonesia. Sebagian lainnya masih berupa potensi yang belum dimanfaatkan karena berbagai keterbatasan seperti kemampuan teknologi dan ekonomi. Kekayaan sumber daya alam tersebut meliputi bahan hutan, tambang, laut, dan sebagainya.

Berdasarkan data yang bersumber dari kompas tahun 2015, kawasan hutan Indonesia mencapai 162 juta hektar. Lahan hutan terluas itu ada di Papua (32,36 juta hektar luasnya). Kemudian hutan Kalimantan (28,23 juta hektar), Sumatera (14,65 juta hektar), Sulawesi (8,87 juta hektar), Maluku dan Maluku Utara (4,02 juta hektar), Jawa (3,09 juta hektar), serta Bali dan Nusa Tenggara (2,7 juta hektar) (Sebelum Hutan Menjadi Kenangan, 2016; http://nasional.kompas.com/read/2015/03/2 1/11422271/Sebelum.Hutan.Menjadi.

Kenangan.html; diakses pada 07 Oktober 2016 pkl. 09.00 Wib).

Indonesia adalah pemilik hutan hujan tropis terluas ketiga di dunia, setelah Brasil dan Kongo. Sayangnya, menurut buku Rekor Dunia Guinness, Indonesia adalah negara yang memiliki tingkat kehancuran hutan tercepat di antara negara- 
negara yang memiliki 90 persen dari sisa hutan di dunia. Menurut buku tersebut, Indonesia menghancurkan luas hutan yang setara dengan 300 lapangan sepak bola setiap jamnya. Forest Watch Indonesia pun mencatat kerusakan hutan di Indonesia dari tahun terus meningkat, sampai saat ini saja sudah mencapai 2 juta hektar per tahun.

Sumber daya alam berikutnya yang dimiliki Indonesia adalah minyak bumi. Minyak bumi (petroleum) atau dikenal juga sebagai emas hitam merupakan cairan kental, cokelat gelap, atau kehijauan yang mudah terbakar yang terdapat pada lapisan teratas dari beberapa area di kerak bumi. Sebagaimana hutan, tidak semua negara memiliki minyak bumi. Kita patut bersyukur, Indonesia menjadi salah satu negara yang memiliki minyak bumi.

Potensi minyak bumi Indonesia terus mengalami penurunan karena dimanfaatkan terus-menerus. Bahkan saat ini, Indonesia telah mulai mengimpor minyak bumi untuk memenuhi kebutuhan dalam negeri yang tak lagi mencukupi. Minyak bumi dimanfaatkan sebagi sumber energi kendaraan bermotor, mesin pabrik, dan lain-lain. Perusahaan Listrik Negara (PLN) sebagian menggunakan minyak bumi untuk menghasilkan listrik.

Kekayaan tambang indonesia berikutnya adalah batu bara. Potensi batu bara di Indonesia yang begitu besar menjanjikan untuk terus dikembangkan. Tingginya cadangan batu bara memungkinkan pemanfaatannya untuk dijadikan energi listrik menggantikan minyak bumi. Berdasarkan data dari Departemen Energi dan Sumber Daya Mineral, produksi batu bara di tahun 2009 mencapai 225 juta ton, yang terbagi atas 75 juta ton untuk pemanfaatan dalam negeri dan 150 juta ton untuk ekspor. Produksi tersebut meningkat dibandingkan tahun 2008 (198 juta ton) dan tahun 2007 (196 juta ton) (Potensi Batu Bara di Indonesia
Menjanjikan, 2016; http://www.kemenperin. go.id lartikel/1224/Potensi-Batu-Bara-diIndonesia-Menjanjikan.html; diakses pada 07 Oktober 2016 pkl 09.00 Wib).

Berdasarkan survei Frasser Institute tahun 2008-2009, dari 71 negara penghasil sumber daya mineral Indonesia menduduki peringkat ke-7 dari segi potensi tetapi menduduki peringkat ke-41 dari segi daerah yang menjadi target investor.

Potensi kekayaan alam selanjutnya adalah gas alam. Perlu untuk diketahui bahwa sumber daya alam yang banyak tersedia di Indonesia adalah gas alam. Indonesia memiliki cadangan gas alam sebesar 2,8 triliun meter kubik (97 triliun kaki kubik). Jumlah ini tidak terlampau besar jika dibandingkan dengan jumlah gas alam yang dihasilkan beberapa penghasil gas alam lainnya. Cadangan gas alam Indonesia hanya $1,5 \%$ dari cadangan gas alam dunia. Negara yang memiliki cadangan gas alam secara berurutan: Rusia 48 triliun meter kubik, Iran 27 triliun meter kubik, dan Qatar 26 triliun meter kubik. Walaupun persentasenya kecil, namun Indonesia merupakan negara pengekspor gas alam terbesar di dunia. Negara tujuan ekspor gas alam Indonesia adalah Jepang, Korea, Taiwan, China, dan Amerika Serikat.

Kekayaan alam dan potensi yang ada di indonesia tidak hanya seputar hasil tambang dan hutan saja, rasanya kurang lengkap kalau tidak membahas tentang sumber daya dan kekayaan laut indonesia. Dua pertiga wilayah Indonesia merupakan lautan. Oleh karena itu, potensi kekayaan laut Indonesia sangat berlimpah. Menurut laporan FAO (Food and Agricultural Organization), potensi lestari sumber daya perikanan tangkap laut Indonesia mencapai sekitar 6,5 juta ton/tahun, dengan tingkat pemanfaatan mencapai 5,71 juta ton/tahun. 
Jika dibandingkan dengan negara lain, produksi ikan tangkap Indonesia menempati urutan ketiga di dunia setelah China dan Peru. Sementara itu, untuk produksi ikan budi daya, Indonesia menempati urutan keempat setelah China, India, dan Vietnam (FAO, 2009).

Kekayaan laut Indonesia juga terlihat dari keanekaragaman hayati biota laut. Laut Indonesia memiliki 8.500 spesies ikan, 555 spesies rumput laut, dan 950 spesies biota terumbu karang. Oleh karena itu, tidak heran jika Indonesia merupakan negara dengan keanekaragaman hayati laut terbesar di dunia (Marine MegaBiodiversity).

\section{a. Optimalisasi Sumber Daya Indonesia}

Dengan berbagai penjelasan tersebut, kita sudah sangat bangga dengan tanah air ini. Begitu besar potensi dan seluruh kekayaan alam yang kita miliki, namun dibalik itu semua tentunya diperlukan upaya Optimalisasi Sumber Daya. Pada dasarnya, kebijakan optimalisasi sumber daya diarahkan agar seluruh sumber daya yang ada baik lahan, laut, mineral, dan jumlah penduduk yang demikian besar dapat dimanfaatkan secara optimal yang dapat juga meminimalisasi sumber daya terlantar dan belum termanfaatkan. Pemanfaatan yang sudah ada saat ini perlu dioptimalisasi agar terjadi peningkatan efisiensi sehingga menciptakan potensi ekonomi yang prospektif yakni dengan menggali sumber daya yang belum termanfaatkan atau terbengkalai. Dengan optimalisasi sumber daya, diyakini bahwa pemanfataan seluruh elemen atau modal sumber daya nasional yang ada, pada tingkat pemanfaatan yang minimal saja sudah dapat memberikan nilai ekonomi dan domino effect yang besar.

Kedaulatan sumber daya alam nasional merupakan modal awal dan sumber pertumbuhan yang tinggi. Dengan kelimpahan sumber daya alam seperti minyak dan gas serta pertambangan seperti emas, tembaga, nikel, alumunium dan batubara, maka Indonesia mampu mencapai pertumbuhan ekonomi hampir 10 persen pada tahun 1980 dan mempertahankan pertumbuhan ekonomi rata-rata di atas 7 persen sejak 1989-1996 (http://www. kompasiana. com/ remy/ optimalisasipotensi-sumber-daya-alam indonesia.html; diakses pada 07 Oktober 2016 pkl. 09.00 Wib).

Sejarah pembangunan ekonomi tersebut menunjukkan betapa strategisnya posisi pengelolaan sumber daya alam dalam pembangunan ekonomi negara-negara kaya sumber daya alam.

\section{b. Pengelolaan potensi dan sumber daya untuk kesejahteraan rakyat indonesia}

Segala pembahasan dalam bab ini merupakan uraian dengan fakta nyata, betapa melimpahnya kekayaan indonesia dan betapa besarnya potensi yang ada yang terkandung di bumi indonesia ini. Hal yang perlu ditekankan tentunya sampai sejauh mana keseriusan pemerintah kita dalam mengelola segala potensi dan kekayaan yang ada ini untuk meningkatkan kesejahteraan seluruh rakyat indonesia, seperti yang tercantum pada pasal 33 ayat 3 UUD RI Tahun 1945, yakni :

"Bumi, air dan kekayaan alam yang terkandung didalamnya dikuasai oleh Negara dan dipergunakan untuk sebesar-besarnya kemakmuran rakyat".

Artinya dengan berdirinya negara indonesia sebagai negara yang merdeka dan berdaulat telah dibuat konsensus yang telah disepakati oleh segenap bangsa dalam rangka mencapai cita-cita dan tujuan bangsa. Maka dalam hal ini, untuk mempermudah distribusi segala potensi dan kekayaan alam indonesia diberlakukanlah prinsip desentralisasi dan otonomi daerah 
berdasarkan prakarsa dan keinginan masyarakat dalam rangka membangun bangsa yang dimulai dari daerah.

Prinsip desentralisasi dan otonomi daerah diberlakukan untuk memberikan kewenangan kepada pemerintah daerah untuk mengurus dan mengatur rumah tangga mereka sendiri dengan penuh rasa tanggung jawab dan tingkat transparansi pemerintahan yang tinggi. Hal ini dilakukan untuk upaya meningkatkan pelayanan kepada masyarakat dan semata-mata untuk dapat pula meningkatkan kesejahteraan masyarakat.

Namun demikian, dengan diberlakukannya pelaksanaan pengelolaan pemerintah daerah dengan prinsip otonomi daerah bukan berarti tidak menimbulkan persoalan dalam pelaksanaannya. Banyak bermunculan daerah pemekaran wilayah baru atau Daerah Otonomi Baru (DOB) otomatis juga akan memberikan beban terhadap Anggaran Pendapatan dan Belanja Negara (APBN) dan belum lagi persoalan terhadap peningkatan kualitas pelayanan terhadap masyarakat yang menjadi tujuan utama dalam prinsip otonomi daerah. Pengelolaan kekayaan indonesia yang berlimpah diperlukan kinerja pemerintah dan pemerintah daerah yang lebih baik lagi.

Dengan bermunculannya daerah pemekaran wilayah baru di berbagai daerah baik itu untuk tingkat kabupaten maupun provinsi diperlukan suatu analisa yang mendalam tentang azas kelayakan terhadap daerah tersebut, apakah benar-benar menjamin keinginan masyarakat tersebut atau tidak dan apakah nantinya benar-benar memberikan efek positif terhadap kehidupan masyarakat di daerah tersebut atau tidak. Agar nantinya benar-benar tercapai keinginan melalui program nasional dalam rangka membangun kehidupan bangsa yang dimulai dari daerah.
Suatu studi keilmuan tentunya tak lepas dari penelitian ilmiah yang dilakukan untuk mengkaji berbagai fenomenafenomena yang ada dalam kehidupan sesungguhnya, tak terkecuali pada ilmu sosial. Secara garis besar, penelitian ilmiah terbagi menjadi penelitian kuantitatif, yaitu penelitian yang bersifat terhitung serta terbukti dengan angka, dan penelitian kualitatif.

Dalam penelitian ini penulis menggunakan metode penelitian kualitatif dengan model penilitian fenomenologi, artinya fenomenologi akan menggali data untuk menemukan makna dari hal-hal mendasar dan esensial dari fenomena, realitas, atau pengalaman yang dialami oleh objek penelitian.

Sebagaimana yang telah dipaparkan bahwa langkah pertama dalam melakukan penelitian fenomenologi adalah meneliti fenomena yang akan dikembangkan. Selanjutnya peneliti mengembangkan pertanyaan penelitian. Dalam mengajukan pertanyaan penelitian ada dua hal yang perlu dipertimbangkan yaitu (Jailani, 2013: 44) : (a) apakah unsur yang penting dari pengalaman atau perasaan, (b) apakah keberadaan pengalaman menentukan hakikat manusia. Sumber data dari penelitian ini adalah fenomena yang sedang dipelajari yang berupa pengalaman subjek yang diteliti.

Data akan dikumpulkan melalui wawancara langsung, observasi, menggunakan video, catatan lapangan. Data yang dikumpulkan diperoleh dari wawancara mendalam antara peneliti dengan informan (subjek). Adapun dalam penelitian ini peneliti juga menggunakan pengumpulan data melalui studi kepustakaan berdasarkan penelitianpenilitian terdahulu yang dapat membantu memperkaya informasi dalam penelitian ini.

\section{Metode}

\section{Pembahasan}


Berdasarkan Undang-Undang RI No. 23 Tahun 2014 Tentang Pemerintahan Daerah Otonomi Daerah adalah:

"Hak, wewenang, dan kewajiban daerah otonom untuk mengatur dan mengurus sendiri Urusan Pemerintahan dan kepentingan masyarakat setempat dalam sistem Negara Kesatuan Republik Indonesia".

Selain itu, otonomi dalam pengertian politik diartikan sebagai hak mengatur sendiri kepentingan intern daerah atau organisasinya menurut hukum sendiri (Marbun, 2007: 350).

Adapun azas dalam penyelenggaraan otonomi daerah ada beberapa azas yakni :

1. Desentralisasi adalah penyerahan Urusan Pemerintahan oleh Pemerintah Pusat kepada daerah otonom berdasarkan Asas Otonomi.

2. Dekonsentrasi adalah pelimpahan sebagian Urusan Pemerintahan yang menjadi kewenangan Pemerintah Pusat kepada gubernur sebagai wakil Pemerintah Pusat, kepada instansi vertikal di wilayah tertentu, dan/atau kepada gubernur dan bupati/wali kota sebagai penanggung jawab urusan pemerintahan umum.

3. Tugas Pembantuan adalah penugasan dari Pemerintah Pusat kepada daerah otonom untuk melaksanakan sebagian Urusan Pemerintahan yang menjadi kewenangan Pemerintah Pusat atau dari Pemerintah Daerah provinsi kepada Daerah kabupaten/kota untuk melaksanakan sebagian Urusan Pemerintahan yang menjadi kewenangan Daerah provinsi.

Perluasan Otonomi Daerah sebagaimana tercermin dalam kebijakan pemerintah melalui Undang-Undang No. 23 Tahun 2014 revisi UndangUndang No. 32 Tahun 2004 tentang Pemerintah Daerah merupakan suatu peluang untuk memberdayakan daerah dalam melaksanakan tugas pemerintahan, pembangunan dan kemasyarakatan. Namun demikian dalam pelaksanaannya ditemukan masalah dan kendala diantaranya, otonomi daerah harus diimplementasikan dalam kerangka orientasi agar daerah benar-benar mampu mengambil inisiatif dan prakarsa kreatif menuju keberlangsungan dan keberhasilan pembangunan daerah yang pada gilirannya, inisiatif dan prakarsa kreatif daerah akan dilaksanakan sendiri dan penentuan hasilnya juga akan kembali kepada daerah yang bersangkutan.

Salah satu aspek yang sangat penting dari pelaksanaan otonomi daerah saat ini adalah terkait dengan pemekaran dan penggabungan wilayah yang bertujuan untuk memperkuat hubungan antara pemerintah daerah dan masyarakat lokal dalam rangka pertumbuhan kehidupan demokrasi. Dengan interaksi yang lebih intensif antara masyarakat dan pemerintah daerah baru, maka masyarakat sipil akan memperoleh hak-hak dan kewajibankewajibannya secara lebih baik sebagai warga negara.

Penentuan dimekarkannya suatu daerah menjadi dua atau lebih daerah otonom pada dasarnya disebabkan oleh konsep objektif agar fungsi pemerintahan mampu dapat dirasakan manfaatnya oleh masyarakat dengan mendasarkan pada hukum dan ketentuan peraturan perundangundangan. Sehingga pemerkaran daerah otonom merupakan keseimbangan antara hak dan tanggung-jawab antara pemerintah daerah dan warga masyarakatnya. 
Penentuan pemekaran daerah sepantasnya didasarkan pada persyaratan yang terukur dengan tiga langkah tujuan preventif, yaitu :

1. Pertama, pemekaran daerah dimaksudkan untuk menguatkan etika profesionalisme dalam pelayanan publik pemerintah daerah kepada masyarakatnya yang akan menciptakan hubungan yang bersifat kesetaraan antara birokrasi dan publik yang dilayani.

2. Kedua, pemekaran daerah ditujukan pada penerapan manajemen dan penguasaan teknologi oleh birokrasi pemerintah daerah untuk melayani publik.

3. Ketiga, pemekaran daerah dilandasi atas profesionalisme, karena rentan kendali yang lebih sempit sehingga pengawasan penyelenggaraan pemerintahan dapat terjamin kualitasnya.

Untuk itulah perlu pertimbangan dan orientasi yang jelas terhadap suatu wilayah jika menginginkan suatu upaya untuk mengatur urusan kewilayahannya sendiri dan lepas dari wilayah induk yang dimaksudkan, bukan sekedar untuk menampung aspirasi masyarakat kebanyakan saja tetapi ada hal yang lebih penting untuk dijadikan sebagai bahan pertimbangan tentang arah dan tujuan yang jelas setelah terlepas dari wilayah induk nantinya. Pembahasan opini mengenai efek negatif dari suatu upaya dalam pemekeran wilayah ini lebih lanjut akan dituangkan dalam tulisan ini dan semoga dapat bermanfaat bagi proses pembelajaran bersama.

Pemekaran daerah dilandasi oleh Undang-Undang Nomor 22 Tahun 1999 tentang Pemerintahan Daerah. Setelah Undang-Undang Nomor 22 Tahun 1999 digantikan dengan Undang-Undang Nomor
32 Tahun 2004 tentang Pemerintahan Daerah, kemudian digantikan lagi dengan Undang-Undang No. 12 Tahun 2008, hingga saat ini diberlakukan UndangUndang No. 23 Tahun 2014 Tentang Pemerintahan Daerah.

Pemekaran daerah dapat dimaknai sebagai pemecahan Daerah provinsi atau Daerah kabupaten/kota untuk menjadi dua atau lebih Daerah baru; atau, penggabungan bagian Daerah dari Daerah yang bersanding dalam 1 (satu) Daerah provinsi menjadi satu Daerah baru. Adapun itu semua dimaksudkan untuk menciptakan kemandirian daerah.

Pembentukan,

pemekaran, penghapusan dan penggabungan daerah berdasarkan Peraturan Pemerintah Republik Indonesia No. 129 Tahun 2000 Tentang Persyaratan Pembentukan dan Kriteria Pemekaran, Penghapusan dan Penggabungan Daerah bertujuan untuk meningkatkan kesejahteraan masyarakat melalui :

1. Peningkatan pelayanan kepada masyarakat.

2. Percepatan pertumbuhan kehidupan demokrasi.

3. Percepatan pelaksanaan pembangunan perekonomian daerah.

4. Percepatan pengelolaan potensi daerah.

5. Peningkatan keamanan dan ketertiban.

6. Peningkatan hubungan yang serasi antara Pusat dan Daerah.

Pemekaran daerah merupakan suatu proses pembagian wilayah menjadi lebih dari satu wilayah, dengan tujuan meningkatkan pelayanan dan mempercepat pembangunan. Pemekaran wilayah juga diharapkan dapat menciptakan kemandirian daerah. Meski demikian terdapat berbagai 
kendala yang muncul dalam proses pemekaran daerah yang dimulai dari tapal batas wilayah, pengaturan keuangan belanja aparatur, perangkat kelembagaan, bantuan daerah induk sampai pada penentuan assetasset daerah yang berakhir pada munculnya konflik antara daerah induk dengan daerah pemekaran.

Permasalahan pemekaran daerah terbagi dalam dua bagian, yaitu

1. Permasalahan yang terjadi pada proses awal pemekaran daerah dan menyebabkan permasalahan baru pada daerah induk dan daerah pemekaran saat pemekaran telah berlangsung, diantaranya : tidak adanya dukungan dan kesepakatan yang jelas antara daerah induk dan daerah pemekaran yang dapat menciptakan permasalahan;

a. Sengketa aset antara daerah induk dan daerah pemekaran,

b. Perebutan sumber daya alam anatar daerah induk dan daerah pemekaran,

c. Sengketa pembagian dana perimbangan antara daerah induk dan daerah pemekaran,

d. Lambannya proses-proses konsolidasi yang berlangsung didaerah pemekaran, sebab dalam masa transisi, daerah pemekaran kurang mendapatkan dukungan SDM dan infrastruktur dari daerah induk.

e. Permasalahan yang timbul akibat tidak tuntasnya prosesproses yang terjadi pada periode pra-pemekaran.

2. Potensi sumber daya dan asset yang ada didaerah berpotensi menjadi rebutan anatara daerah induk dan daerah pemekaran. Perebutan terhadap penguasaan sumber daya dan asset daerah seringkali berpotensi konflik yang berbuntut pada tidak meksimalnya pengelolaan dan penggunaan sumber daya dan asset tersebut. Hal ini memberikan gambaran betapa buruknya penataan wilayah daerahdaerah pemekaran dan tidak siapnya mengelola daerah dengan prinsip otonomi. Penyerahan asset sebagaimana diatur dalam Pasal 9 ayat (1) Keputusan Menteri Dalam Negeri Nomor 42 Tahun 2001 dilaksanakan selambat-lambatnya 1 (satu) tahun terhitung sejak tanggal peresmian Provinsi/Kabupaten/Kota yang baru dibentuk (Keputusan Menteri Dalam Negeri No. 42 tahun 2001). Penentuan jangka waktu tersebut dinilai terlalu cepat mengingat kondisi geografis, suasana politik daerah dan adat istiadat ditiap daerah tidak sama. Seharusnya dalam menentukan jangka waktu penyerahan asset ditentukan dalam beberapa tahapan yakni jangka pendek, jangka menengah dan jangka panjang dengan pembatasan selama 5 (tahun).

Disamping itu, salah satu permasalahan berkaitan dengan keberadaan pemekaran daeran adalah di seputar Peraturan Daerah (Perda) yang dipandang bermasalah berawal dari temuan Kamar Dagang dan Industri (Kadin) Indonesia, bahwa ada 1.006 Perda di seluruh Indonesia yang dianggap memberatkan dunia usaha (Fahmi, 2009: 111). Atas temuan tersebut Presiden akhirnya Menginstruksikan Departemen Dalam Negeri (Depdagri) untuk melihat dan memonitor pelaksanaan otonomi daerah agar tidak membebani para pengusaha di daerah. Dari temuan tersebut Depdagri melakukan kajian intensif terhadap seluruh Perda yang dikeluarkan oleh Daerah Kabupaten dan Kota di Indonesia. 
Disamping itu, tidak ada sanksi administrasi yang tegas bagi daerah induk yang belum atau tidak menyerahkan asset kepada daerah pemekaran sampai jangka waktu yang ditentukan terlampaui. Sehingga dalam penerapannya, daerah induk tidak memiliki rasa takut dan bersikap mengulur-ulur waktu penyerahan. Keputusan Menteri Dalam Negeri Nomor 42 Tahun 2001 dinilai hanya sebatas pedoman bagi instansi terkait dalam melaksanakan proses pembagian asset daerah pemekaran. Apabila tidak sesuai pedoman yang diberikan tidak diberikan sanksi yang tegas.

Perlu diketahui hingga tahun 2007, Menurut data yang dilansir harian Kompas, sampai tahun 2007 daerah otonom baru yang sudah terbentuk sebanyak 173 daerah, terdiri atas 7 provinsi, 135 kabupaten dan 31 kota. Hingga saat ini, Kementerian dalam negeri menerima 114 usulan pemekaran daerah otonom baru dari masyarakat dalam empat bulan terakhir. Jika ditambah 87 usulan daerah otonom dari DPR, kini ada 201 usulan pemekaran daerah otonom baru. Saat ini Indonesia memiliki 34 provinsi dan 508 kabupaten/kota. Berdasarkan kajian Kemendagri, 65 persen daerah otonom tersebut gagal berkembang.

\section{Dampak Positif Pemekaran Daerah}

Adanya pemerintahan daerah, maka pluralisme yang ada dalam masyarakat negara baik sosial, budaya, ekonomi dan lainnya bisa ditampung dalam wadah pemerintahan daerah masing-masing sehingga tidak mengarah kepada otokrasi sentral. Dalam wilayah mereka, keragaman yang ada dalam masyarakat tetap terpelihara sehingga menjadi akar kebangsaan, tanpa kemudian harus menaifkan ciri-ciri khusus kedaerahan yang ada. Melalui pemerintahan daerah juga bisa diberi kesempatan yang lebih luas bagi penduduk untuk ikut berpartisipasi dalam penyelenggaraan pemerintahan daerah mereka, melalui bermacam-macam dewan daerah baik yang bersifat politik (seperti DPRD di Indonesia) maupun ekonomi (misalnya Komite Perlindungan Konsumen Daerah) atau sosial misalnya Dewan Pemangku Adat Daerah dan sebagainya. Masyarakat juga mempunyai kesempatan untuk memperoleh pilihan yang lebih banyak, dari pelayanan umum yang disediakan pemerintahan daerah selain yang disediakan oleh pemerintahan secara nasional.

Disamping itu kehadiran pemerintahan daerah, bisa mendorong demokrasi melalui :

1. Tambahan kesempatan bagi masyarakat untuk memberikan suaranya, melalui pemilihanpemilihan lokal.

2. Memberikan hak yang luas bagi warganya untuk berpartisipasi aktif dalam penyelenggaraan pemerintahan termasuk kegiatan dalam kelompok penekan.

3. Politisi lokal memiliki tanggung jawab yang lebih besar pada pemilihannya ketimbang para pejabat atau politisi di pusat.

4. Merupakan latihan atau sekolah untuk membangun sistem yang demokratis.

5. Pemerintah Daerah sebagai wakil komunitas sub nasional dalam lingkungan daerah tertentu, bisa mendorong terwujudnya negara bangsa.

6. Memperluas pemahaman individu kearah pemahaman konsep kebangsaan yang lebih luas, sehingga misalnya tidak menganggap bahwa pemungutan suara sekedar cermin kepentingan pribadi tetapi juga untuk kepentingan bangsa/nasional. 
7. Masyarakat lokal didorong untuk menyelesaikan sendiri konflikkonflik yang terjadi secara internal, tanpa campur tangan Pusat sehingga bisa meningkatkan stabilitas nasional.

8. Memungkinkan kebijaksanaan-kebijaksanaan inovatif dan alternatif. Kesalahan yang ditimbulkan oleh kebijaksanaan Daerah jauh lebih kecil akibatnya ketimbang akibat keputusan pemerintah Pusat.

Hal yang menjadi fokus utama dalam pembahasan pemekaran wilayah selanjutnya adalah beberapa alasan yang mendukung argumen pentingnya kebijakan pemekaran untuk mengatasi masalah nasional antara lain (Harian Kompas bulan (Maret 2005; http://cahwaras. wordpress. com/2010/04/25/keputusan-menteri-dalamnegeri-nomor-42-tahun-2001-tentangpedoman-pelaksanaan-penyerahan-barangdan-hutang-piutang-pada-daerah-yangbaru-dibentuk/; diakses pada 8 mei 2013).

\section{Pembangunan Ekonomi Nasional}

Pemekaran merupakan strategi untuk menciptakan dan mendorong munculnya aktivitas perekonomian dan akselerasi pertumbuhan ekonomi didaerah perbatasan dan tertinggal. Kehadiran daerah-daerah baru akan mendorong pembangunan infrastruktur dasar dan sarana-saran pelayanan publik dasar.bila berbagai infrastruktur dasar sudah memadai maka sangat terbuka peluang daerah tersebut akan mengalami pertumbuhan ekonomi yang lebih akseleratif.

2. Pembangunan Politik Nasional: Penguatan Identitas KeIndonesiaan

Pemekaran akan mendekatkan pelayanan pada masyarakat sehingga negara akan dirasakan kehadirannya sangat riil oleh masyarakat. Yang menarik kehadiran negara dalam hal ini tidak dengan wajah koersif tapi lebih pada pemberian pelayanan. Kondisi ini akan memupuk identitas keIndonesiaan yang lebih kuat karena masyarakat di daerah pemekaran akan merasakan manfaat langsung dari pelayanan publik yang ada serta merasa diperlakukan sama dengan warga negara yang lain. Mereka akan tetap merasa menjadi bagian dari bangsa Indonesia.

3. Pembangunan Pertahanan dan Keamanan:Penjagaan Kewilayahan Aktif.

Pembentukan daerah pemekaran baru bisa mendorong adanya penjagaan wilayah secara aktif. Misalnya kasus klaim ladang minyak di Ambalat akan memberikan motivasi tersendiri bagi Kaltim agar Propinsi Kalimantan Utara (Kaltara) bisa cepat terbentuk sehingga ada upaya pengawasan intensif terhadap wilayah Indonesia. Dengan terbentuknya Kaltara maka jarak pengawasan akan semakin dekat. Berbagai instansi/kantor/lembaga/badan setingkat Propinsi akan terbentuk, termasuk untuk mendukung pengamanan teritorial wilayah NKRI.

Desentralisasi yang melahirkan pemerintah daerah diperlukan karena sangat bermanfaat untuk :

1. Meredam in efisiensi didalam sistem pemerintahan yang dikontrol secara sentral (oleh pemerintah Pusat).

2. Sebagai alat/sarana privatisasi berbagai kegiatan masyarakat (termasuk yang merupakan pelayanan publik).

3. Mengurangi ketegangan dalam bidang keuangan pada tingat pemerintah nasional. 


\section{Dampak Negatif Pemekaran Daerah}

Pemekaran daerah yang melahirkan prinsip otonomi daerah merupakan sistem yang sangat baik dalam tata kelola pemerintahan tanpa menghilangkan hubungan yang saling terikat antara pemerintah dan pemerintah daerah. Banyaknya bermunculan Daerah Otonom Baru (DOB) atau daerah pemekaran baru bukannya tidak meninggalkan masalah, ada beberapa hal yang perlu diketahui dengan adanya pemerintah daerah baru yang lahir dari proses pemekaran daerah, yakni :

\section{Banyaknya Peraturan Daerah yang bermasalah}

Hingga tahun 2016, saat ini melalui kementerian dalam negeri RI telah mencatat ada sekitar 1.665 Peraturan Daerah (Perda) bermasalah. Sebelumnya, melalui Presiden RI telah membatalkan 3.143 Perda yang dianggap bermasalah karena menghambat kecepatan dalam menghadapi kompetisi meningkatkan investasi (Presiden Umumkan Pembatalan 3.143 Perda Bermasalah, 2016; http:// www. kemendagri.go.id/news/ 2016/06/13/ presiden-umunkan-pembatalan-3143perda-bermasalah.html; diakses pada 10 Oktober 2016 pkl. 10.00 wib).

Kebebasan pemerintah daerah dalam pelaksanaan otonomi daerah tercermin dari aturan yang dihasilkan oleh daerah tersebut dalam rangka melindungi hak dan kewajiban masyarakat. Aturan tersebut seharusnya tidak bertentangan dengan citacita nasional dan tidak pula merugikan masyarakat yang ada didalamnya.

\section{Daerah Otonom Baru dapat membebankan APBN}

Tak dapat dipungkiri bahwa pemekaran pemerintah daerah ini telah menimbulkan tekanan terhadap APBN akibat adanya sejumlah dana yang harus ditransfer kepada pemerintah daerah baru. Kondisi ini memberikan pesan kepada pemerintah pusat untuk membuat kriteria yang jelas dan tegas dalam menyetujui pemekaran pemerintah daerah baru. Motivasi untuk membentuk daerah baru tidak terlepas dari adanya jaminan dana transfer dari pemerintah pusat kepada pemerintah daerah. Dalam era desentralisasi ini, bentuk dana transfer ini dikenal sebagai dana perimbangan yang terdiri dari Dana Alokasi Umum (DAU), Dana Alokasi Khusus (DAK), serta Dana Bagi Hasil baik bagi hasil pajak maupun bagi hasil sumber daya alam. Aliran dana inilah yang akan ditransfer kepada pemerintah daerah termasuk pemerintah daerah baru berdasarkan kriteria dan formula tertentu.

$\begin{array}{cccr}\text { Pada } & 2003, & \text { sebanyak } & 22 \\ \text { kabupaten/kota } & \text { baru } & \text { sebagai } & \text { hasil }\end{array}$ pemekaran sepanjang 2002 telah menerima DAU sebesar Rp 1,33 triliun. Jumlah ini terus meningkat pada APBN 2004, 40 daerah hasil pemekaran 2003, telah menerima DAU Rp 2,6 triliun (http://www.antikorupsi.org/id/content/ pemekaran-pemerintah-daerah-dan-bebanapbn-250804.html; diakses pada 10 Oktober 2016 pkl. 10.00 wib).

Jumlah DAU daerah pemekaran ini tentunya juga akan mengurangi jumlah DAU yang diterima daerah induk sehingga memiliki potensi yang besar pula terjadinya degradasi pada pelayanan publik dan penyediaan infrastruktur kepada masyarakat. Dampak yang lebih luas dari hal ini adalah adanya kemungkinan beban terhadap APBN bertambah lagi dengan adanya intervensi yang harus dilakukan oleh pemerintah pusat dalam membangun daerah pemekaran ini.

Pada 2003, APBN harus menyalurkan dana Rp 88 miliar hanya untuk membangun prasarana pemerintahan daerah pemekaran atau setiap daerah pemekaran akan mendapatkan dana sebesar Rp4 miliar. 
Jumlah ini terus bertambah pada APBN 2004 menjadi Rp 228 miliar. Menurut data Direktorat Jenderal Perimbangan Keuangan Kementerian Keuangan, pada tahun 1999 total DAU yang ditransfer ke daerah baru Rp 54,31 triliun. Pada tahun 2009, jumlah itu melonjak menjadi Rp 167 triliun (http://www.kemenkeu.go.id/sites/default/ files/ 2013_kajian_pkapbn_ Menyibak_ Kegagalan_Pemekaran_RTH.pdf; Diakses pada 10 Oktober 2016 pkl. 10.00 wib).

3. Daerah Otonom Baru dimanfaatkan untuk kepentingan sekelompok orang saja

Belakangan terungkap, sebagian daerah otonom baru hasil pemekaran ternyata sesungguhnya tidak layak berpisah dari daerah induk. Pemekaran daerah otonom baru hanya memicu kelahiran birokrasi gemuk yang kental dengan bagibagi jabatan dan menjalankan roda pemerintahan mengandalkan anggaran dari transfer pemerintah pusat.

Pembentukan daerah otonom baru selama ini sarat proses transaksi. Kajian pemekaran sering kali menjiplak dari kajian pemekaran daerah lain. Ditambah lagi angka-angka indikator yang dipalsukan agar daerah itu terlihat memenuhi syarat untuk berdiri sendiri. Hal-hal ini harus menjadi pelajaran pemerintah supaya tidak terulang lagi dalam pemekaran daerah ke depan. Dengan demikian, daerah otonom baru yang terbentuk betul-betul bisa mensejahterakan rakyat, bukan justru gagal berkembang, membebani negara dan masyarakatnya.

\section{Konflik DOB dengan daerah induk}

Munculnya DOB kebanyakan kasus justru menimbulkan konflik baru khsusunya dengan daerah induk, masasalah-masalah yang banyak muncul tersebut diantaranya adalah masalah aset daerah yang menjadi perebutan antara DOB dan daerah induk, belum lagi masalah tapal batas wilayah. Selain itu, masalah yang sering muncul antara DOB dan daerah induk adalah masalah perebutan potensi dan sumber daya alam yang terkandung didaerah tersebut ketika masih bergabung.

5. Korupsi mewabah siring dengan banyaknya pemekaran daerah baru

Korupsi itu tanda kualitas pelayanan publik buruk. Data pertumbuhan ekonomi daerah hasil pemekaran dengan data di kementerian daerah tertinggal menunjukkan cukup banyak daerah baru langsung masuk kategori daerah tertinggal. Mungkin kita ingat kelaparan di Yahukimo, Papua. Yahukimo adalah hasil pemekaran daerah. Jadi, ketika pemekaran dilakukan, malah kelaparan kelaparan muncul. Ini berarti layanan publiknya tidak jalan. Sebagai bahan catatan Menurut, Pendiri Institut Otonomi Daerah, Prof Djohermansyah Djohan, mengatakan 80 persen daerah otonomi baru masih membebani pemerintah pusat. Hanya 20 persen yang berhasil. Ini berdasarkan jumlah 223 daerah otonomi baru pada satu dekade terakhir (https://nasional.tempo.co/read/news/2016 /10/08/ 078810688/80-persen-kabupatenkota-hasil-pemekaran-masih-menyusu-kepusat.html; diakses pada 10 Oktober 2016 pkl. 10.00 wib).

Korupsi di tingkat daerah semakin mewabah seiring dengan pemekaran 205 daerah baru. Niat baik untuk mengembangkan daerah justru menambah jumlah praktek korupsi daerah yang mencapai 30 jenis korupsi.

Situasi ini, juga tampak dalam laporan semester pertama tahun 2011 Badan Pemeriksa Keuangan tentang adanya 358 laporan Keuangan Pemerintah Daerah yang menunjukkan kerugian sebanyak 1.197 kasus dengan nilai Rp 376 miliar (https://m.tempo.co/read/news/2012/02/11/ 063383242/korupsi-mewabah-seiring- 
dengan-pemekaran -daerah-baru.html; diakses pada 10 Oktober 2016 Pkl. 10.00 Wib).

6. Kualitas pelayan publik dan In-efisiensi kinerja aparatur pemerintahan daerah

Kualitas terhadap pelayanan publik merupakan indikator utama dalam upaya pemekaran daerah baru. Terbentuknya DOB diharapkan mampu meningkatkan kualitas pelayanan publik disemua lini, selain itu juga mampu meningkatkan kesejahteraan masyarakat. Namun, dari beberapa kasus justru dengan adanya DOB tidak mampu mewujudkan hal-hal seperti yang diharapkan tersebut.

Lambannya DOB dalam membenahi berbagai hal sehingga masih memiliki ketergantungan dalam penyelenggaraan pemerintahan terhadap daerah induk dan pemerintah pusat. Dengan kondisi seperti inilah kemudian lama kelamaan apabila kemandirian DOB tidak terwujud dalam jangka waktu tertentu akan mengorbankan kepentingan masyarakat khsusunya dalam penyelenggaraan pelayanan publik. Buruknya kualitas pelayanan publik oleh aparatur pemerintah kepada masyarakat di DOB juga dipengaruhi karena kualitas SDM nya yang masih belum siap. Kesiapan DOB dalam menyelenggarakan pemerintahan yang mandiri memberikan tuntutan kepada para aparatur untuk siap dengan misi tersebut.

\section{SIMPULAN}

Penyelenggaraan Otonomi Daerah merupakan bentuk tanggungjawab setiap daerah dalam mencapai tujuan yang diharapkan, yakni :

1. Meningkatkan kualitas pelayanan publik kepada masyarakat.

2. Meningkatkan daya saing daerah dan
3. Meningkatkan

kesejahteraan masyarakat di daerah.

Dalam penjelasan ini perlu ditekankan bahwa perlu adanya kajian mendalam oleh pemerintahan melalui DPD (Dewan Perwakilan Daerah) dalam rangka merumuskan sebuah aturan tentang penyelenggaraan otonomi daerah ini serta analisa yang matang dalam menerima usulan daerah tentang pembentukan DOB (Daerah Otonomi Baru) atau Daerah Pemekaran Baru agar dapat meminimalisir dampak negatif dari DOB nantinya.

Perlu adanya kajian tentang kebutuhan masyarakat dan tingkat urgensinya terhadap suatu permasalahan khususnya dalam bidang pelayanan untuk melahirkan DOB.

Tujuan dibentuknya otonomi daerah yang dibarengi dengan tingkat kesadaran masyarakat akan pelayanan oleh pemerintah merupakan hal yang sangat penting dan melatarbelakangi munculnya DOB, namun tanpa harus mengenyampingkan persoalan-persoalan utama dari munculnya DOB atau Daerah Pemekaran Baru nantinya.

Munculnya DOB tentunya dapat menambah beban terhadap APBN namun itu merupakan tanggung jawab utama dibentuknya sebuah organisasi pemerintahan namun yang paling penting adalah dengan adanya otonomi daerah dan munculnya DOB ini tujuan pemerintahan secara menyeluruh dapat tercapai bukan hanya sekedar untuk mencapai tujuan sekolompok golongan saja.

\section{DAFTAR RUJUKAN}

\section{Buku :}

Fahmi, Sudi. 2009. Hukum Otonomi Daerah.Yogyakarta : Kreasi Total Media 
Gaffar, Affan. 2007. Otonomi Daerah Dalam Negara Kesatuan. Yogyakarta : Pustaka Belajar

Gayo, Iwan. 2010. Buku Pintar Seri Senior. Banten : Pustaka Warga Negara

Karim, Abdul Gafar. 2003. Kompleksitas Persoalan Otonomi Daerah Di Indonesia. Yogyakarta : Pustaka Belajar

Marbun, BN. 2007. Kamus Politik. Jakarta : Pustaka Sinar Harapan

\section{Jurnal \& Media Berita :}

M. Syahran Jailani. 2013. RAGAM PENELITIAN QUALITATIVE (Ethnografi, Fenomenologi, Grounded Theory,dan Studi Kasus), Jurnal Edu-Bio, Vol 4

Wasisto Raharjo Jati. 2012. Inkonsistensi Paradigma Otonomi Daerah Di Indonesia : Dilema Sentralisasi atau Desentralisasi, Jurnal Konstitusi, Universitas Gajah Mada FK Ilmu Sosial dan Ilmu Politik, VOL 9 No. 4 Tahun 2012 744-773

Kemendagri Perketat Pemekaran Daerah Baru, 2015; Versi cetak artikel ini terbit di Harian Kompas edisi 11 Juli 2015, di halaman 4 dengan judul "Kemendagri Perketat Pemekaran Daerah Baru".

\section{Peraturan :}

UUD Republik Indonesia Tahun 1945

UU Republik Indonesia No. 23 Tahun 2014 Tentang Pemerintahan Daerah

Peraturan Pemerintah Republik Indonesia No. 129 Tahun 2000 Tentang Persyaratan Pembentukan dan Kriteria Pemekaran, Penghapusan dan Penggabungan Daerah

Keputusan Menteri Dalam Negeri Nomor 42 Tahun 2001 Tentang Pedoman Pengelolaan Barang Daerah

\section{Website :}

Penduduk Indonesia Tahun 2013; http://indonesia2050.info/umum/lua s-wilayah-dan-jumlah-penduduk/; diakses tanggal 06 November 2018

Sebelum Hutan Menjadi Kenangan, 2016; http://nasional.kompas.com/read/20 15/03/21/11422271/Sebelum.Hutan. Menjadi. Kenangan.html; diakses pada 07 Oktober 2016 pkl. 09.00 Wib

Potensi Batu Bara di Indonesia Menjanjikan, 2016; http://www. kemenperin. go.id /artikel/ 1224/ Potensi-Batu-Bara-di-IndonesiaMenjanjikan.html; diakses pada 07 Oktober 2016 pkl 09.00 Wib

Maret 2005; http://cahwaras. wordpress. com/2010/04/25/keputusan-menteridalam-negeri-nomor-42-tahun2001-tentang-pedomanpelaksanaan-penyerahan-barangdan-hutang-piutang-pada-daerahyang-baru-dibentuk/; diakses pada 8 mei 2013

Presiden Umumkan Pembatalan 3.143 Perda Bermasalah, 2016; http:// www. kemendagri.go.id/news/ 2016/06/13/ presiden-umunkanpembatalan-3143-perda-

bermasalah.html; diakses pada 10 Oktober 2016 pkl. 10.00 wib

Korupsi Mewabah, 2016; https://m.tempo.co/read/news/2012/ 02/11/ 063383242/korupsimewabah-seiring-denganpemekaran -daerah-baru.html; diakses pada 10 Oktober 2016 Pkl. $10.00 \mathrm{Wib}$

Kabupaten Kota hasil Pemekaran, 2016; https://nasional.tempo.co/read/news /2016 /10/08/ 078810688/80-persenkabupaten-kota-hasil-pemekaranmasih-menyusu-ke-pusat.html; diakses pada 10 Oktober 2016 pkl. $10.00 \mathrm{wib}$ 
Kegagalan Pemekaran Wilayah, 2016; Harian Kompas bulan Maret 2005. http://www.kemenkeu.go.id/sites/def ault/ files/ 2013_kajian_pkapbn_ Menyibak_ Kegagalan_ Pemekaran_RTH.pdf; Diakses pada 10 Oktober 2016 pkl. 10.00 wib

Beban APBN Dalam Pemekaran Wilayah, 2016;

http://www.antikorupsi.org/id/conte nt/ pemekaran-pemerintah-daerahdan-beban-apbn-250804.html; diakses pada 10 Oktober 2016 pkl. 10.00 wib Dalam<http://cahwaras.wordpress. com/2010/04/25/keputusan-menteridalam-negeri-nomor-42-tahun2001-tentang-pedomanpelaksanaan-penyerahan-barangdan-hutang-piutang-pada-daerahyang-baru-dibentuk/>

Pemekaran Pemerintah Daerah, 2016 ; http://www.antikorupsi.org/id/conte nt/ pemekaran-pemerintah-daerahdan-beban-apbn-250804; diakses pada 10 Oktober 2016 pkl. 10.00 wib 